\title{
Die resepsie van retoriese momente van die Filemonbrief deur Patristiese eksegete
}

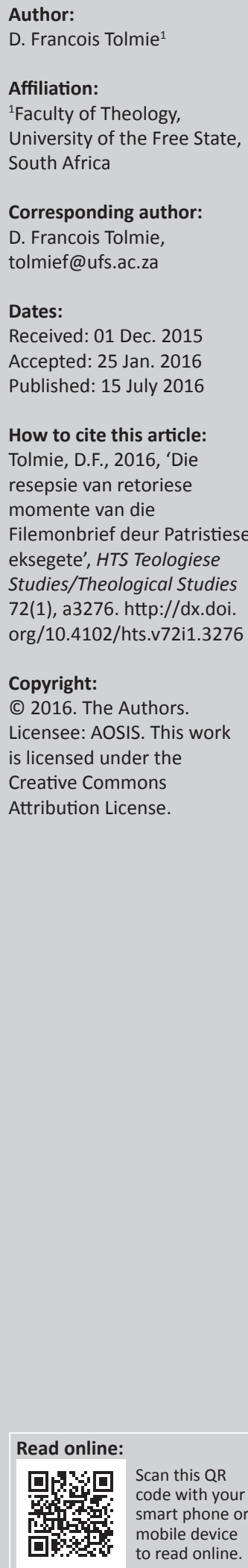

\begin{abstract}
The reception of rhetorical elements in the Letter to Philemon by Patristic exegetes. The aim of this study is to offer an overview of the way in which Patristic exegetes interpreted the rhetorical aspects of Paul's Letter to Philemon. Although a rhetorical analysis of the letter was not the matter which interested them as such, one can still obtain a fairly good idea of the way in which they perceived such aspects by reading their explanations of this letter. Accordingly, the contributions of all the Patristic exegetes in this regard are studied systematically in this study. The interpretations of the letters by Ambrosiaster, Jerome, John Chrysostom, Pelagius, Theodore of Mopsuestia and Theodoret of Cyrus are investigated from this angle. In each case, the most important comments on Paul's rhetorical strategy are identified and discussed.
\end{abstract}

\section{Inleidend}

Die retoriek van die Filemonbrief het al heelwat aandag gekry, en vanuit heelwat verskillende perspektiewe. Ek noem enkeles: Die retoriek van die brief is al ondersoek vanuit die perspektief van die klassieke retoriek (bv. Church 1978:17-33), die verhouding tussen die briefgenre en die retoriek (bv. Nottingham 1991; Weima 2010:29-60), die kulturele retoriek (bv. Kea 1996: 223-232), die ooreenkoms en verskil in die strategie wat in dié brief gevolg word en die strategie wat in Plinius se brief aan Sabinianus gevolg word (Barclay 2004:103-111), die strategie wat tipies in eerste-eeuse versoekbriewe gevolg is (Russell 1998:1-25), magsverhoudinge in die brief (bv. Elliott 2011:51-64; Frilingos 2000:91-104), sosio-retoriese benaderings (bv. Witherington 2007:51-97), 'n teks-gesentreerde benadering (Snyman 2009:178-193), die wyse waarop emosies in die brief funksioneer (Lampe 2010:61-78) en stilistiese aspekte (Wendland 2010:79-112). 'n Perspektief wat egter nog baie min aandag gekry het, is die wyse waarop Patristiese eksegete die retoriese elemente in die brief geïnterpreteer het. Ek het reeds elders aandag gegee aan twee van die Patristiese eksegete (Tolmie 2014:1-8, 2015:1-7), maar daar is nog verskeie ander Patristiese eksegete wie se werk nog nie vanuit hierdie perspektief bestudeer is nie. Daarom word daar in hierdie studie aandag gegee aan die wyse waarop al die Patristiese eksegete wie se geskrifte behoue gebly het die Filemonbrief geïnterpreteer het. Die spesifieke saak wat aan die orde kom, is die resepsie van retoriese elemente in die Filemonbrief deur hierdie eksegete. ${ }^{1}$ Nou is dit natuurlik so dat dit nie hulle bedoeling was om die retoriek van die brief te bespreek nie. Dit het vir hulle eerder daaroor gegaan om aan te dui wat Paulus se boodskap vir gelowiges van hulle eie tyd was. ${ }^{2}$ Tog is dit ook waar dat 'n mens uit hulle werke 'n goeie idee kan kry van hoe hulle die retoriek van die brief verstaan het, en dit is hierdie aspek wat in hierdie studie belig word.

\section{Ambrosiaster}

Hierdie kommentaar is tydens die tyd van Pous Damasus, dit wil sê 366-384 n.C., deur 'n onbekende Christen ${ }^{3}$ (waarskynlik 'n lid van die kerklui in Rome) in Latyn geskryf (Kannengiesser 2006:1081). Ambrosiaster se kommentaar is die oudste kommentaar op die Filemonbrief wat behoue gebly het en sy primêre bedoeling was om Paulus se boodskap in hierdie brief vir die mense van sy tyd duidelik te maak (Kannengiesser 2006:1082).

Vir die doeleindes van hierdie studie lig ek drie aspekte uit.

1.Die begrip Patristiek word in hierdie artikel gebruik soos deur Kannengiesser (2006:3) gedefinieer, naamlik die era tot en met die val van die Romeinse Ryk, d.w.s. tot en met die sewende eeu n.C. in die Weste en tot en met die negende eeu n.C. in die Ooste.

2.Kyk byvoorbeeld na Mitchell (2001:339) se opmerkings hieroor (met verwysing na Chrysostomus).

3.Kyk na Bray (2009:xv-xvi). Daar is vir'n geruime tyd aanvaar dat die naam Ambrosiaster deur Desiderius Erasmus geskep is, maar dit is nie korrek nie. Die skepper daarvan was waarskynlik Franciscus Lucas Brugensis in sy Notationes van 1580. Kyk na Krans (2013:274-281) vir'n goeie bespreking hiervan. 
Eerstens, Ambrosiaster se siening van wat ons deesdae die retoriese situasie van die brief sou noem, stem ooreen met wat later as die tradisionele siening bekend geword het $t^{4}$ : Onesimus was 'n ongelowige slaaf wat sy Christen-eienaar kwaad gemaak het en toe gevlug het. Hy is later deur Paulus gedoop en toe na Filemon teruggestuur. Ambrosiaster noem die Filemonbrief ' $n$ persoonlike brief en vermeld ook dat Paulus wou hê dat Filemon vir Onesimus moes terug ontvang. Filemon moes verder ook vir God vir Onesimus dank omdat Filemon hom nie net as slaaf sou terugontvang nie, maar ook as 'n geliefde broer (in Philm. arg., 337.4-75). Aangesien Ambrosiaster die oudste kommentaar op die Filemonbrief is wat behoue gebly het, is dit dus ook die eerste keer dat 'n mens dit so verwoord kry, maar soos wat Mitchell (1995:145-147) aantoon, was dit op hierdie stadium alreeds 'n algemeen-aanvaarde beskouing aangesien dié gedagte ook elders in die Patristiese literatuur (by outeurs wat nie kommentare op die Filemonbrief geskryf het nie) voor die tyd van Ambrosiaster se kommentaar voorkom. Wat wel interessant is, is die manier waarop Ambrosiaster hierdie prentjie verder inklee. In sy kommentaar op verse 10-14 wys hy daarop dat Paulus vir Onesimus gedoop het omdat hy na goddelike hulp (ad divinum auxilium; in Philm. 10-14, 339.22) gevlug het. In sy kommentaar op verse 15-16 verduidelik hy verder dat Onesimus, ná 'n lang reis, by Paulus toevlug gevind het (confugit longa peregrinatione ad apostolum; in Philm. 15-16, 340.5-6). Ongelukkig brei hy nie hierop uit nie, maar dit wil voorkom asof Ambrosiaster van mening was dat Onesimus doelbewus na Paulus toe gevlug het om hulp te kry, of dan in sy woorde, om goddelike hulp te kry. Indien dit wel die geval is, is Ambrosiaster die enigste eksegeet in die Patristiese era wat die situasie op hierdie manier ingesien het, aangesien die ander almal gedink het dat Onesimus toevallig by Paulus in die gevangenis uitgekom het. As hierdie interpretasie van Ambrosiaster se verduideliking korrek is, is dit ' $n$ belangrike aspek om raak te sien aangesien dit as verdere ondersteuning vir Lampe ${ }^{6}$ se voorstel vir die ontstaan van die brief kan dien.

'n Tweede belangrike aspek is die groot klem wat Ambrosiaster in sy brief op hiërargie plaas. In Ambrosiaster se tyd is daar wyd gedebatteer oor die gesag van biskoppe, ouderlinge en diakens (Hunter 2009:14-21) en daarom is dit nie vreemd dat hierdie aspek vir hom so belangrik was nie. Hy beklemtoon gevolglik dikwels die hiërargiese verhouding tussen Paulus en Filemon. Ek bied enkele voorbeelde: Volgens Ambrosiaster het Filemon nie enige kerklike amp beklee nie, maar was hy een van die leke (in Philm. arg., 337.4-5). Aan die ander kant was Paulus 'n apostel en het hy dus apostoliese gesag gehad en kon hy aan Filemon opdragte gee aangesien Filemon sy dissipel was (in Philm. 1-7, 338.24). In sy verduideliking van vers 7 wys Ambrosiaster ook daarop dat Paulus 'n belangriker 4.Kyk na Tolmie (2009:279-301) vir'n vollediger bespreking van hierdie aspek.

5.Verwysings is na die teks in Vogels (1968). Vir 'n Engelse vertaling, kyk na Bray (2009:161-163).

6.Volgens Lampe (1985:135-137) moet Onesimus nie as ' $n$ wegloopslaaf beskou word nie, aangesien sy bedoeling nie was om permanent weg te loop nie. Hy het doelbewus na Paulus gevlug sodat Paulus as bemiddelaar tussen hom en Filemon kon optree sodat hy dan weer na Filemon se huis kon terugkeer. posisie gehad het as die ander gelowiges vir wie Filemon reeds gehelp het en dat Filemon dus geen ander keuse gehad het as om hom te gehoorsaam nie (in Philm. 1-7, 338.24). Wat veral opvallend is, is die plek wat Ambrosiaster binne hierdie hiërargie aan Onesimus toeken. Normaalweg sou hy aan die onderpunt van die hiërargie lê, dit wil sê Paulus (apostel) in die belangrikste posisie, gevolg deur Filemon (volgens Ambrosiaster was hy Paulus se dissipel), met Onesimus as slaaf heel onder in die hiërargie. In sy kommentaar wys Ambrosiaster egter daarop dat Paulus vir Onesimus sy broer en seun noem, wat volgens hom impliseer dat Onesimus dus Paulus se gelyke geword het. Hy het dus opgeskuif vanaf die laagste punt in die sosiale hiërargie na die hoogste punt en omdat Paulus Filemon se meerdere was, het Onesimus dus ook Filemon se meerdere geword. Ambrosiaster wys eksplisiet daarop dat Onesimus die broer van Filemon se leermeester geword het (in Philm. 15-16, 340.8-9). Paulus se versoek dat Filemon vir Onesimus moet ontvang soos wat hy Paulus sou ontvang, word selfs deur Ambrosiaster verbind aan 'Salomo' se uitspraak in Sirag 10:25 dat vry mense (in hierdie geval Filemon) 'n wyse slaaf (in hierdie geval Onesimus) sal dien (in Philm. 17, 340.16-22). Ambrosiaster spel nie die praktiese implikasies uit wat dit vir Filemon se huishouding sou inhou nie, maar 'n mens kan jou voorstel dat hy van mening moes gewees het dat dit vir Filemon in 'n moeilike posisie sou plaas. 'n Mens kry selfs plek-plek die indruk dat Ambrosiaster gedink het dat Filemon dit moeilik sou gevind het om Paulus se versoek te eerbiedig. Enkele voorbeelde in hierdie verband is die volgende: In sy verduideliking van verse 15-16 wys hy daarop dat slaweeienaars dikwels 'n arrogante houding teenoor hulle slawe gehad het en hy argumenteer dat Paulus na Onesimus as sy broer verwys om te verhoed dat Filemon so 'n houding inslaan (in Philm. 15-16, 340.7-12). In sy bespreking van vers 17 wys hy selfs daarop dat Paulus in hierdie vers probeer om Filemon skrik te maak sodat hy ten minste bereid sou wees om Onesimus uit vrees terug te ontvang as Paulus dit nie kon regkry om hom te oortuig om dit uit liefde te doen nie (in Philm. 17, 340.16-22). In die geval van vers 18 wys Ambrosiaster daarop dat Paulus se bedoeling in hierdie vers was om enige verskoning weg te neem wat Filemon sou kon hê om nie vir Onesimus te vergewe nie (in Philm. 18, 340.24-25). Hierdie realistiese evaluering van die moontlike effek wat Paulus se brief sou hê, is skaars onder die Patristiese eksegete. Die enigste ander persoon wat iets soortgelyks noem, is Theodorus van Mopsuestia. Al die ander was van oortuiging dat Paulus se brief baie suksesvol sou wees.

Derdens lig ek ook enkele van die interessante maniere uit waarop Ambrosiaster van die detail-aspekte in die Filemonbrief interpreteer. Volgens hom noem Paulus homself 'n gevangene van Christus (v. 1) om die waardigheid van sy brief aan te dui (in Philm. 1-4, 337.13). As rede vir Paulus se blydskap (v. 7) noem hy die feit dat Paulus seker was dat Filemon sou doen wat in die brief van hom verwag word (in Philm. 7, 338.21-24). Dat Paulus eerder by Filemon pleit as om aan hom 'n opdrag te gee, word verduidelik deur die opmerking dat Filemon'n goeie mens was (in Philm. 8-9, 339.2). 
Die oproep wat Paulus in verse 10-14 doen, word as 'n aanduiding van Paulus se nederigheid geïnterpreteer (in Philm. 10-14, 339.19), en in verse 17-22 identifiseer Ambrosiaster verskeie wisselings in Paulus se retoriese strategie: vers 17 is bedoel om Filemon die skrik op die lyf te jaag (in Philm. 17, 340.20-22), vers 18 moet enige verskoning vir woede aan Filemon se kant wegneem (in Philm. 18, 340.23-25), in vers 20 behandel Paulus vir Filemon op 'n sagte manier (in Philm. 20, 341.14-18), terwyl vers 22 weer bedoel is om Filemon te dwing om gehoorsaam te wees (in Philm. 22, 341.21-25).

\section{Hieronimus}

Hieronimus het sy interpretasie van die Filemonbrief tussen 386 en 388 n.C. geskryf, dit wil sê kort nadat hy na Betlehem verhuis het. Dit was die eerste van sy vier werke oor die Pauliniese Briewe (Friedl 2010:289-290). Hieronimus het sy werk op Origenes se kommentaar (wat ongelukkig verlore gegaan het) gebaseer (kyk bv. na Souter 1927:100-138; Von Harnack 1918-1919:141-146).

Anders as Ambrosiaster was daar by Hieronimus geen twyfel oor die sukses wat Paulus se brief sou hê nie. So beklemtoon hy byvoorbeeld in sy bespreking van verse 1-3 dat Paulus beslis sou kry wat hy van Filemon verwag (in Philm. 1-3, $84.70-72^{7}$ ), en in die geval van verse $10-13$ merk hy op dat Filemon dit nie sou waag om nee te sê nie (in Philm. 10-13, 96.383-384).

Wat die retoriese situasie van die brief betref, verduidelik Hieronimus dat Onesimus van Filemon se besittings gesteel het en toe na Italië gevlug het sodat hy nie maklik gevang sou kon word nie. Daar het hy toe Filemon se geld op 'n spandabelrige manier vermors (in Philm. 8-9, 94.336-339). Hy het egter later tot geloof gekom en hom van sy vroeëre lewe bekeer en is deur Paulus gedoop - wat beteken dat Paulus self die getuie van die egtheid van sy bekering was (in Philm. 8-9, 94.344-358). Paulus het hom toe na Kolosse teruggestuur met twee briewe: 'n brief aan die hele gemeente en 'n privaat brief met aanbevelings aan Filemon (in Philm. 1-3, 85.11-13). Ambrosiaster was van mening dat Paulus wou hê dat Filemon vir Onesimus weer as slaaf en as geestelike broer moes terugontvang. Hieronimus het dinge egter anders gesien. Volgens hom wou Paulus eintlik hê dat Onesimus sy (= Paulus se) medewerker in sy sendingwerk moes word (in Philm. 8-9, 94.352-95.353; kyk ook verder in Philm. 15-16, 98.446-447). Ongelukkig gee Hieronimus nie meer inligting hieroor nie, maar wat wel duidelik is, is dat hy anders oor dié saak geoordeel het as Ambrosiaster.

Hieronimus lewer ook gereeld kommentaar op dit wat ons vandag Paulus se retoriese strategie sou noem. Ek bied enkele voorbeelde. Volgens Hieronimus:

- noem Paulus homself 'n gevangene van Christus in plaas van ' $n$ apostel van Christus omdat eersgenoemde groter rede tot trots was (in Philm. 1-3, 83.68-84. 71)

7.Verwysings is na die kritiese uitgawe van Bucchi (2003:75-106). Vir ' $n$ Engelse vertaling, kyk na Scheck (2010:351-382).
- noem Paulus Timoteus as mede-sender van die brief omdat die brief dan meer gesag sou dra (in Philm. 1-3, 86.138-142)

- is die volgorde van die name Filemon, Apfia en Argippus (vv. 1-2) belangrik omdat Apfia se naam doelbewus in die middel geplaas word sodat sy deur die ander twee (mans) ondersteun kan word (in Philm. 1-3, 88.194-197)

- is die feit dat Paulus in vers 4 'jou' in die enkelvoud gebruik, 'n aanduiding dat die brief eintlik net 'n gesprek tussen Paulus en Filemon is alhoewel die brief tegnies deur Paulus en Timoteus aan Filemon, Apfia en Argippus en die kerk in Filemon se huis gerig word (in Philm. 4-6, 89.211-216);

- prys Paulus eers doelbewus vir Filemon uitvoerig voordat hy by sy versoek kom (in Philm. 8-9, 94.329-335)

- verander Paulus sy retoriese strategie in verse 10-13: hy pleit nie langer vir Filemon se slaaf nie, maar nou vir sy eie seun (in Philm. 10-13, 95.361-363)

- benut Paulus in vers 17 die feit dat Filemon graag sy vennoot wil wees: hy kan Paulus se vennoot word as hy bereid sou wees om Onesimus ook as sy vennoot te aanvaar (in Philm. 17, 98.459-99.467)

- bied hy 'n interessante verduideliking vir Paulus se onderneming om Filemon te vergoed vir enige skade wat Onesimus veroorsaak het: Paulus praat nou met Filemon asof hy 'n vreemdeling is, maar eintlik was daar 'n besondere verhouding tussen hulle - hulle het alles met mekaar gedeel (in Philm. 19, 99.479-489).

Uit Hieronimus se werk is dit ook duidelik dat hy Paulus se brief baie noukeurig gelees het. Hy wys byvoorbeeld op dubbelsinnighede in verse 2 en 4 : Na wie se huis verwys Paulus in vers 2, na Filemon s'n of na Argippus s'n? (in Philm. 1-3, 88.180-184). En verwys die 'altyd' in vers 4 na die feit dat Paulus altyd vir God dank of dat hy altyd aan Filemon in sy gebede dink (in Philm. 4-6, 89.213-216)? Daar is egter ook gevalle waar Hieronimus se interpretasie verkeerd is. Hy besef byvoorbeeld nie dat Paulus in vers 5 'n chiasme gebruik nie (liefde ... geloof ... Here Jesus Christus ... al die gelowiges) en vind dit dan nodig om 'n uitgerekte verduideliking te gee wat Paulus bedoel met die stelling dat ' $n$ mens geloof in ander gelowiges moet hê (in Philm. 4-6, 89.225-93.311). En in die geval van vers 22 verstaan hy die woord hospitium verkeerd as verwysende na 'n aparte woning en nie na 'n gastekamer in Filemon se huis nie (kyk ook Scheck 2010:376 vn. 143) en vind dit dan nodig om daarop te wys dat Paulus nie so 'n groot plek versoek het omdat hy spandabelrig was nie, maar omdat hy besef het dat daar baie mense sou opdaag om na sy prediking te luister. In sommige gevalle bied hy ook vreemde verklarings vir wat Paulus in die brief doen. So byvoorbeeld verduidelik hy Paulus se verwysing na Filemon as geliefde deur 'n onderskeid te tref tussen

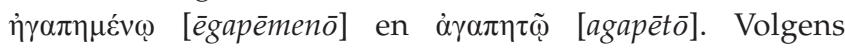
Hieronimus kan eersgenoemde gebruik word om na enige persoon te verwys, selfs na mense wat nie liefde verdien nie, terwyl laasgenoemde (wat Paulus in hierdie geval gebruik) slegs gebruik kan word om te verwys na mense 
wat liefde waardig is (in Philm. 1-3, 87.151). 'n Laaste voorbeeld is die volgende: Teen die einde van sy werk bied hy' $n$ vreemde uitleg van die betekenis van al die persoonlike name in die brief. ${ }^{8}$

\section{Chrysostomus}

Johannes Chrysostomus het nie 'n kommentaar oor die Filemonbrief geskryf nie, maar sy homilieë oor die brief bevat ' $n$ rykdom van inligting wat vir hierdie studie van nut is. ${ }^{9}$ Weens die oorvloed inligting wat Chrysostomus oor hierdie saak verskaf, beperk ek hierdie bespreking tot die

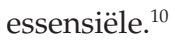

Eerstens beskou Chrysostomus die retoriese situasie soos volg: Filemon, 'n goeie mens, se slaaf, Onesimus, het iets by hom gesteel en toe gevlug. Hy het uitgekom by Paulus, wat in Rome in die gevangenis was. Paulus het hom in die Christelike geloof onderrig en hom toe gedoop. Hierna het Paulus ' $n$ aanbevelingsbrief aan Filemon geskryf sodat hy Onesimus kon vergewe en hom as 'n nuwe mens kon terugontvang (hom. in Philm. arg., 326.8-1111). Verderaan wys Chrysostomus spesifiek daarop dat Onesimus as 'n slaaf teruggestuur is en dat dit Paulus se bedoeling was dat hy as 'n slaaf in Filemon se huis moes aanbly (hom. in Philm. arg., 327.21-28). Chrysostomus het dus 'n ander siening as Hieronimus oor hierdie saak gehad.

Tweedens is die mate waartoe Chrysostomus sy interpretasie van Paulus se retoriek in terme van eer en skande as kategorieë beskryf, opvallend. In huidige interpretasies van hierdie saak verwys navorsers by geleentheid hierna (kyk bv. na Church 1978:27; Lampe 2010:70), maar dit word nooit so konsekwent gedoen soos wat Chrysostomus dit doen nie. 'n Mens kan dit byvoorbeeld alreeds aan die begin van sy uitleg sien. Terwyl huidige studies oor die retoriek van die brief gewoonlik die verhouding tussen Paulus en Onesimus as uitgangspunt neem (kyk bv. na Church 1978:20; Fitzmyer 2000:23), fokus Chrysostomus op Filemon. Volgens Chrysostomus was Filemon 'n eerbare man (hom. in Philm. arg., 325.1-3) en is die brief primêr 'n brief aan 'n slaweeienaar oor sy slaaf (hom. in Philm. arg., 326.8-10). Later noem hy dat Paulus nie skaam was om Onesimus na Filemon terug te stuur nie (hom. in Philm. arg., 327.12-16). Die begrip wat hy

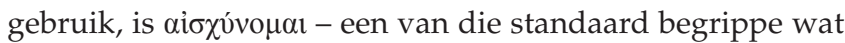
in die antieke wêreld gebruik is om na die eer-skandesisteem te verwys (kyk bv. na Domeris 1993:284). Verderaan in sy homilieë verwys Chrysostomus dan ook gereeld na eerskande-kategorieë, en wel op twee maniere. Soms verwys hy na die effek wat Paulus se woorde op Filemon sou hê. Dit sou hom beskaam het in die sin dat hy te verleë sou wees om

8.Hy kry dit waarskynlik by Origenes (Friedl 2010:299, vn. 90) en gebruik dit ook as 'n manier om die boodskap van die brief op te som (Decock 2010:279-280).

9.Dit is nie presies seker wanneer die homilieë geskryf is nie. Sommige navorsers, bv. Quasten (1960:448-449), plaas hulle tydens Chrysostomus se tydperk in Antiogië (386-397 v.C.), terwyl andere, bv. Kelly (1995:132-133), hulle tydens sy tydperk in Konstantinopel plaas.
Kont

10.Kyk na Tolmie (2014:1-8) vir 'n vollediger bespreking van hierdie saak.

11.Verwysings is na die teks van Field (1849-1862). anders op te tree as wat deur die samelewing van hom verwag is. Twee voorbeelde ondersteun hierdie argument: In Chrysostomus se bespreking van verse $1-3$ begin hy deur die effek van hierdie woorde op Filemon uit te lig: Dit sou hom kalmeer, keer dat hy beskaam sou staan en sy woede stil (hom. in Philm. 1-3, 328.32-329.1). Die tweede voorbeeld is die volgende: In die geval van vers 7 (waar Paulus sy blydskap uitspreek dat Filemon die harte van ander gelowiges verkwik het) noem Chrysostomus dat niks ons so beskaam as wanneer iemand ons herinner aan die goedheid wat ons teenoor ander mense betoon het nie, veral nie as die persoon wat ons daaraan herinner op baie meer geregtig is as die mense vir wie ons reeds gehelp het nie (hom. in Philm. $7,336.23)$

In ander gevalle funksioneer die eer-skande-kategorie op 'n ander manier, naamlik met die klem op 'n verandering in die eer waarop iemand geregtig was. As voorbeeld noem ek die volgende: Paulus se verwysing na die kerk in Filemon se huis word (verkeerdelik) deur Chrysostomus geïnterpreteer as slegs 'n verwysing na die slawe in Filemon se huishouding, wat dan deur hom verstaan word as 'n manier waarop Paulus hulle eer. Hy wys egter ook daarop dat Paulus hulle nie eksplisiet noem nie, volgens hom 'n doelbewuste keuse om seker te maak dat hy nie Filemon beledig nie; hy eer dus die slawe sonder om die slawe-eienaar te ontstig (hom. in Philm. $1-3,330.10-24)$. Later, in sy bespreking van vers 10 , wys Chrysostomus ook op die verandering in Onesimus se status. Hy het nou iemand geword wat eer waardig is (hom. in Philm. $10,338.15-16) .{ }^{12}$ Paulus se versoek verderaan in die brief om Onesimus te ontvang, word op soortgelyke wyse geïnterpreteer: Dit beteken nie net dat Onesimus waardig was om deur Filemon vergewe te word nie, maar ook dat hy waardig was om eer te ontvang; hy was immers nou Paulus se seun (hom. in Philm. 12, 339.9-11).

Derdens maak ek enkele opmerkings oor Chrysostomus se siening van detail-aspekte van Paulus se retoriese strategie in die Filemonbrief. Soos reeds vermeld, gee hy 'n oorvloed inligting hieroor en daarom word dit hier tot die essensie beperk. Dikwels stem sy insigte ooreen met beskouinge van huidige navorsers, maar in sommige gevalle lig hy ander aspekte uit. Ek noem enkele voorbeelde hiervan. In die geval van vers 3 redeneer hy dat Paulus die woord genade gebruik omdat hy doelbewus vir Filemon daaraan wil herinner dat God sy sonde vergewe het. Sy doel is dat Filemon God, sy Eienaar, se voorbeeld sal volg in sy optrede teenoor sy eie slaaf (hom. in Philm. 1-3, 330.24-27). In die geval van verse 4-6 merk Chrysostomus op dat Paulus doelbewus eers aan ander sake aandag skenk voordat hy sy versoek rig om sodoende die indruk te vermy dat Onesimus die enigste rede was hoekom hy die brief geskryf het (hom. in Philm. 4-6, 335.18-31). Vers 8 ('Al het ek die reg om aan jou 'n opdrag te gee ...'; eie vertaling - FT) word deur Chrysostomus as 'n kompliment aan Filemon beskou. Dit toon dat Paulus hom as 'n groot man beskou het wie se optrede in die verlede tot gevolg gehad het dat Paulus soveel vertroue in hom sou hê 12.Kyk na De Wet (2010:325) vir'n goeie bespreking oor hierdie saak. 
(hom. in Philm. 8, 337.5-18). In vers 11 (waar Paulus daarop wys dat Onesimus nou bruikbaar vir sowel Filemon as homself geword het) bespeur Chrysostomus 'n a minore ad maius argument: As Onesimus vir Paulus - wat soveel noukeurigheid vereis het - bruikbaar was, hoeveel te meer sou hy nie vir Filemon bruikbaar wees nie (hom. in Philm. 11, 338.18-25). ' $n$ Laaste voorbeeld is die volgende: Die feit dat Paulus na Epafras as 'n medegevangene verwys (v. 23), word deur Filemon geïnterpreteer as 'n manier om druk op Filemon uit te oefen: Epafras was ook van Kolosse afkomstig en as hy bereid was om saam met Paulus te ly, hoe kon Filemon Paulus se versoek oor Onesimus weier? (hom. in Philm. 24, 349.7-9)

\section{Pelagius}

Pelagius se kommentaar het in Rome ontstaan en het uit sy onderrig aan Christene in aristokratiese kringe gespruit. Dit is tussen 405 en 410 n.C. geskryf (Kannengiesser 2006:1236; kyk ook na Levy 2011:24). Dit is later twee keer hersien, onder andere deur Cassiodorus en sy studente wat probeer het om wat hulle as Pelagiaanse foute beskou het, te verwyder (De Bruyn 1993:27-28).

Pelagius verstaan die retoriese situasie soos volg: Paulus skryf die brief uit die gevangenis in Rome ter wille van Onesimus, Filemon se slaaf, wat deur hom (Paulus) gedoop is. Volgens Pelagius het Paulus vir Onesimus gedoop omdat hy geweet het Onesimus sou makliker van sy eienaar genade ontvang as hy reeds van God genade ontvang het. Pelagius merk ook op dat Paulus vir Onesimus terugstuur om te gaan regmaak wat hy verbrou het en dat hy in die toekoms reg sou optree (in Philm. arg., 536.1-4 ${ }^{13}$ ).

Pelagius se kommentaar op die brief is kort, en daar is nie veel wat vir die doeleindes van hierdie studie belangrik is nie. Die enigste aspek wat opvallend is, is dat hy wat ek as een van die belangrikste aspekte in die brief beskou, naamlik die manier waarop die verhouding tussen Filemon en Onesimus verander het as gevolg van die feit dat Onesimus 'n gelowige geword het, heeltemal ignoreer. Vir Pelagius val die fokus deurentyd op Paulus. Volgens hom is daar niks wat belangriker in die brief is as Paulus se nederigheid nie (in Philm. arg., 536.5-7). Hy vermeld ook gereeld Paulus en Filemon se voorbeeldige gedrag. Die enigste manier waarop Onesimus ter sprake kom, is in die rol van 'n slaaf wat sy taak gehoorsaam uitvoer: Paulus belowe dat hy in die toekoms reg sal optree (in Philm. arg., 536.4); hy spreek die vertroue uit dat Onesimus hom (Paulus) goed sal dien (in Philm. 13, 538.7-10); selfs Paulus se verwysing na Onesimus as 'nie as 'n slaaf nie, maar as 'n geliefde broer' (v. 16; eie vertaling - FT) word deur Pelagius slegs op een manier verstaan, naamlik as dat Onesimus voortaan vir Filemon gewillig sal dien (in Philm. 16, 539.1-2). Die feit dat die Filemonbrief op so 'n vreemde manier binne 'n Christelike konteks geïnterpreteer kon word, moet as 'n waarskuwingsteken dien oor die groot invloed wat ons eie voorveronderstellings kan hê wanneer ons met tekste omgaan.

13.Verwysings is na die teks in Souter (1926).

\section{Theodorus van Mopsuestia}

Theodorus se kommentare op die Pauliniese briewe is laat in die eerste of vroeg in die tweede dekade van die vyfde eeu n.C. geskryf. Soos Fitzgerald (2010:345-354) aantoon, was daar veral twee sake wat vir Theodorus in sy uitleg van die Filemonbrief belangrik was, naamlik dat dit nog relevant was vir die gelowiges van sy tyd en dat die brief nie beteken dat Christen-slawe vrygelaat moet word nie.

Theodorus bied 'n uitgebreide beskrywing van die retoriese situasie: Onesimus was die slaaf van Filemon, 'n godsdienstige man, en het met bose bedoelings van sy eienaar gevlug. Terwyl Paulus in die gevangenis in Rome was, het hy vir Onesimus herken as iemand wat uit Filemon se huishouding afkomstig was en hom toe oorreed om sy vroeëre kwaadwilligheid te laat staan en hom ook oortuig om vrywillig terug te keer na Filemon se huis en voortaan gehoorsaam te wees. In sy brief vra Paulus dan vir Filemon om vir Onesimus te vergewe en hom met 'n goeie gesindheid terug te ontvang (in Philm. arg., 772.1-14 ${ }^{14}$ ).

Soos Ambrosiaster lees Theodorus ook Paulus se brief in terme van 'n hiërargie, maar in sy geval val die klem op orde, in die sin van 'n natuurlike orde soos deur God gewil. Gevolglik tref hy deurgaans 'n onderskeid tussen Paulus as 'n apostel, Filemon as 'n (blote) gelowige en Onesimus as 'n slaaf wat in onguns verval het, 'n gelowige geword het en na sy vorige posisie moet terugkeer. Volgens Theodorus weerspieël ook die volgorde van die name in verse 1-2 (Filemon, Apfia, Argippus en die kerk in Filemon se huis, laasgenoemde verstaan as die slawe in sy huis) die orde van die natuur (pa, ma, hulle seun en hulle slawe) (in Philm. 1-2, 789.4-6).

Theodorus blyk 'n baie noukeurige leser van Paulus se brief te wees. In verskeie gevalle wys hy byvoorbeeld op wat Paulus nie skryf nie. In die geval van vers 1 wys hy daarop dat Paulus doelbewus nie na homself as 'n slaaf van Christus of as 'n apostel verwys nie om te verhoed dat die indruk geskep word dat hy sy apostoliese gesag op Filemon afdwing (in Philm. 1a, 784.5-20), en in die geval van verse 8-9 verduidelik hy dat Paulus nie sy apostelskap vermeld nie en ook nie noem dat hy 'n hoër posisie as Filemon het nie, maar dat hy eerder konsentreer op die liefde wat Filemon vir die ander gelowiges het (in Philm. 8-9a, 792.13-27). In ander gevalle vestig Theodorus die aandag op die volgorde van Paulus se woorde. Die voorbeeld van die volgorde van die name van die ontvangers van die brief is reeds hierbo genoem. Wat meer is, in vers 11 ('bruikbaar sowel vir jou as vir my'; eie vertaling - FT) noem Paulus volgens hom doelbewus eers vir Filemon voordat hy homself noem omdat hy daardeur wil aandui dat alles wat gebeur het eintlik tot Filemon se voordeel was (in Philm. 11, 794.27-796.9). In sommige gevalle vestig hy ook die aandag op 'n spesifieke woord wat Paulus gebruik. So redeneer hy byvoorbeeld dat

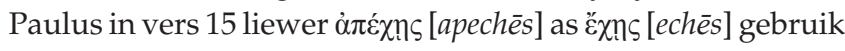
14.Verwysings is na die teks in Greer (2011:772-805). 
omdat eersgenoemde 'ontvang [hom] terug' beteken, terwyl laasgenoemde net 'hê [hom]' beteken (in Philm. 15, 800.1-3).

Ten opsigte van die manier waarop Theodorus die detail van Paulus se retoriese strategie interpreteer, moet vier aspekte uitgelig word: Eerstens verstaan hy Paulus se verwysing na homself as 'Paulus, 'n ou man' as 'n manier om Filemon tot gehoorsaamheid te beskaam. Soos Fitzgerald (2010:361) aantoon, was beskaming een van die standaard retoriese tegnieke wat in daardie tyd in die onderrig van die retoriek gebruik is, en is dit vermoedelik die rede waarom Theodorus Paulus se strategie op hierdie manier verstaan. Dit is ook belangrik om daarop te let dat Theodorus dit nie in 'n negatiewe sin bedoel nie, aangesien hy wat Paulus hier doen, koppel aan die bewondering wat die naam Paulus tot gevolg sou hê (in Philm. 9, 792.31). Tweedens beklemtoon Theodorus die groot impak wat Paulus se verwysing na Onesimus as sy kind op Filemon sou hê. Volgens hom sou hierdie woord op sy eie genoeg gewees het om Filemon te oorreed (in Philm. 10, 794.12-15). Derdens is dit interessant om daarop te let dat Theodorus vers 17 ('As jy my as jou vennoot beskou ...'; outeur se eie vertaling) as die hoogtepunt van Paulus se oorredende strategie in die brief beskou. Theodorus argumenteer dat hierdie stelling gebaseer is op die veronderstelling dat die wat glo, alles met mekaar gemeen het. Aangesien Paulus bereid was om Onesimus terug te neem, moet Filemon ook bereid wees om hom terug te neem (in Philm. 17, 802.6-13). Fitzgerald (2010:362) wys tereg daarop dat Theodorus hier uitgaan van een van die belangrikste sieninge oor vriendskap in die antieke wêreld, naamlik dat vriende alles met mekaar gemeen het. Omdat Paulus en Filemon vriende was, moet Filemon dus bereid wees om aan Paulus se versoek te voldoen. Laastens noem Theodorus heel onverwags teen die einde van sy kommentaar dat dit lyk asof Paulus onseker was of sy brief die gewenste effek op Filemon sou hê. Hy baseer dit op die feit dat Paulus dit nodig gevind het om in vers 21 te noem dat hy seker was dat Filemon aan sy versoek sal voldoen (in Philm. 20, 804.8-12).

Ten slotte moet nog op een geval gewys word waar Theodorus iets wat Paulus geskryf het, verkeerd verstaan het. Die woord

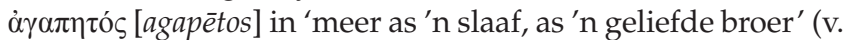
16), verwys na die feit dat Paulus vir Onesimus lief was en dat Filemon ook vir hom lief moes wees. Theodorus verstaan dit egter anders, naamlik as dat Paulus bedoel het dat Onesimus vir Filemon lief sou wees. Hy sou in die toekoms nie net teenoor Filemon onderdanig wees soos wat slawe normaalweg teenoor hulle eienaars was nie, maar hom ook liefhê (in Philm. 15-16, 798.25-802.2). 'n Mens wonder hoekom Theodorus die woord verkeerd verstaan het. Was dit vir hom so moeilik om vir homself 'n slawe-eienaar voor te stel wat 'n slaaf liefhet dat hy dit intuïtief verstaan het as die liefde wat van Onesimus se kant teenoor sy eienaar verwag is?

\section{Theodoret van Cyrus}

Theodoret het sy kommentaar op die Pauliniese briewe iewers tussen die jare 431 en 447 of 448 n.C. geskryf. Hy het dit tot 'n groot mate op die werk van Johannes Chrysostomus en Theodorus van Mopsuestia gebaseer (Guinot 2006:890-893).
Theodoret se verstaan van die retoriese situasie van die brief stem tot ' $n$ groot mate ooreen met die van Chrysostomus en Theodorus van Mopsuestia: Filemon, 'n gelowige, het in Kolosse gewoon. Onesimus, sy slaaf, het iets van hom gesteel en toe gevlug. In Rome het die situasie egter verander toe hy vir Paulus in die gevangenis ontmoet het, want hy is deur Paulus gedoop en teruggestuur na sy eienaar (in Philm. arg., 287.1-815). Later in sy kommentaar wys Theodoret op die positiewe uitkoms wat Paulus se brief gehad het: Op grond van die brief het Filemon vir Onesimus teruggestuur na Paulus wat hom toe saam met Tigikus na die Kolossense gestuur het (in Philm. 14, 290.31-291.1).

Wat die retoriese elemente van die Filemonbrief betref, is daar nie veel in Theodoret se kommentaar nie. Ek lig wel enkele opmerkings uit om te wys hoe hy by geleentheid die detail van Paulus se argument verstaan. Volgens hom noem Paulus homself ' $n$ gevangene om sy pleidooi meer waardig te maak (in Philm. 1-3, 288.3-4). Paulus se verwysing na Filemon as sy medewerker word deur Theodoret as 'n kompliment verstaan (in Philm. 1-3, 288.8-9). Soos Theodorus van Mopsuestia vind hy ook Paulus se verwysing na homself as 'Paulus, 'n ou man' baie treffend. Hy noem dit roem en verduidelik dat Paulus daardeur suggereer dat al sy harde werk vir die evangelie sy hare laat grys word het en dat dit sy woorde meer oortuigend gemaak het. Deur nog ook 'gevangene van Christus' by te voeg, het Paulus dit reggekry om Filemon se respek vir hom verder te laat toeneem (in Philm. 8-9, 289.12-28). In verse 10-11 wys Theodoret daarop dat Paulus eers vir Onesimus prys deur hom sy seun te noem en dat hy eers daarna sy naam noem (in Philm. 10-11, 289. 30-290.8). Hy vind ook Paulus se versoek in vers 17 (dat Filemon vir Onesimus moes terugontvang omdat Paulus en Filemon vennote was) baie effektief (in Philm. 17, 291.11-13). Soos ander eksegete voor hom is hy ook van mening dat vers 22 (Paulus se versoek om vir hom 'n gastekamer reg te hou) 'n aanduiding is dat Filemon wel aan Paulus se versoek gehoor sou gee omdat hy besef het dat Paulus op pad was na Kolosse (in Philm. 22, 292.9-10). Om saam te vat: Theodoret beweeg dus nie werklik verder as dit wat hy by Chrysostomus en Theodorus van Mopsuestia gekry het nie. Die belangrikste bydrae wat hy lewer, is die klem op die effek wat die brief op Filemon sou gehad het. Nou en dan bied hy wel sy eie interpretasie, byvoorbeeld sy stelling dat vers 9 deur Paulus as roem bedoel is.

\section{Gevolgtrekking}

Wat het hierdie ondersoek opgelewer?

Eerstens moet daarop gewys word dat al die Patristiese eksegete die retoriese situasie van die Filemonbrief breedweg gesproke min of meer op dieselfde manier verstaan het, naamlik in terme van wat later as die tradisionele perspektief bekend sou word: Paulus het die Filemonbrief vanuit ' $n$ gevangenis in Rome geskryf ter wille van Filemon se slaaf wat gevlug het, maar deur Paulus se toedoen tot bekering 15.Verwysings is na die uitgawe van Marriott en Pusey (1870:287-292). 
gekom het, gedoop is en toe na Filemon teruggestuur is. Wat egter gewoonlik misgekyk word, is dat hierdie breë prentjie op verskillende maniere deur die Patristiese eksegete ingeklee word - 'n aanduiding van hoeveel gapings daar in die teks is vir latere lesers wat nie eerstehandse kennis van die situasie het nie. So byvoorbeeld was Ambrosiaster van mening dat Paulus wou hê dat Filemon vir Onesimus in sy huishouding moes terug verwelkom en noem hy selfs dat Onesimus na goddelike hulp gevlug het. Hieronimus (wat gedink het Paulus het vir Onesimus met twee briewe na Kolosse gestuur) verstaan die situasie egter anders. Volgens hom het Paulus die brief geskryf omdat hy wou hê Filemon moes vir Onesimus toelaat om sy (= Paulus) sendingvennoot te word. Hieronimus het ook 'n heelwat meer uitgebreide prentjie van wat alles met Onesimus gebeur het voordat hy Paulus ontmoet het: Hy het van Filemon se eiendom gesteel, na Italië gevlug sodat hy nie maklik gevang sou kon word nie en toe die gesteelde goedere daar verkwansel en die geld vermors. Chrysostomus se siening stem weer min of meer ooreen met die van Ambrosiaster: Paulus het vir Onesimus teruggestuur om weer 'n slaaf in Filemon se huishouding te wees, en Paulus wou hê dat Filemon hom moes vergewe. Pelagius voeg weer 'n eie aksent by: Paulus het Onesimus gedoop omdat hy geweet het Filemon sou hom makliker vergewe as hy reeds van God genade ontvang het. Theodorus van Mopsuestia het ook unieke aspekte: Volgens hom het Paulus (in die gevangenis) vir Onesimus herken as iemand wat aan Filemon se huishouding behoort het en hom toe suksesvol oorreed om 'n gelowige te word. Dit het gemaak dat hy vrywillig na Filemon teruggekeer het. Theodoret sien alles weer as 'n twee-stap proses: Onesimus het eers die brief wat oor homself gehandel het na Filemon geneem en is toe op grond van die brief deur Filemon teruggestuur na Paulus, wat hom toe saam met Tigikus weer met 'n tweede brief na Kolosse teruggestuur het. Hieruit blyk dat daar dus allermins onder hierdie eksegete konsensus oor die detailaspekte van die retoriese situasie was - 'n saak wat sover ek kon vasstel nog nooit in die hedendaagse gesprek oor die retoriek of die ontstaansituasie van die brief geopper is nie. Gewoonlik word net aanvaar dat al die Patristiese eksegete die tradisionele siening aanvaar het. Dit is wel breedweg korrek, maar die feit dat hulle dit op verskillende maniere inkleur, verdien ook aandag en toon dat ' $n$ mens nie sonder meer kan aanvaar dat die tradisionele perspektief die korrekte een is omdat dit van altyd so aanvaar is nie. Daar was onder hierdie groep eksegete onderlinge verskille wat ook aandag verdien.

Wat die manier betref waarop die Patristiese eksegete Paulus se retoriese strategie verstaan het, het dit geblyk dat dit dikwels ooreenstem met die manier waarop navorsers dit deesdae verstaan. Daar is egter ook verskille. Soms interpreteer hulle die brief ooglopend verkeerd, soos wat gebeur met Hieronimus se verduideliking van $\alpha \gamma \alpha \pi \eta \tau$ ć $\varsigma$ [agapètos] in vers 1 (Theodorus van Mopsuestia maak ook 'n fout in sy verduideliking van hierdie begrip in v. 16). Hieronimus verstaan ook die begrip hospitium in vers 22 verkeerd. Verder is dit ook opvallend dat verskeie van die eksegete 'die kerk in jou huis' uitsluitlik op die slawe in Filemon se huis betrek.
In ander gevalle verskil hulle interpretasie van die manier hoe ons dit deesdae doen, maar kan hulle siening nie sonder meer afgewys word nie. Inteendeel, dit sou wys wees om sulke interpretasies ten minste in te sluit by die reeks geldige moontlikhede wat deur ons geïdentifiseer word. Ek noem slegs enkeles om die punt te illustreer: Die feit dat Ambrosiaster (en later ook Theodorus van Mopsuestia) klaarblyklik bedenkinge gehad het oor die moontlike sukses wat die brief sou hê, moet as 'n waarskuwing vir ons dien teen oor-optimistiese sienings oor die sukses wat die brief sou hê. In die werklike wêreld verloop dinge dikwels anders as wat dit vir ons in ons studeerkamers voorkom. Verder is dit wel waar dat Ambrosiaster, en later ook Theodorus van Mopsuestia, se klem op hiërargie in hulle interpretasie van die brief konflikte binne die kerk van hulle tyd weerspieël, maar dit mag nie daartoe lei dat ons hierdie belangrike aspek miskyk nie. Die kritiese vraag wat ons vir onsself moet afvra, is of ons moderne interpretasies van die brief nie weer te ver in die ander rigting neig nie, naamlik na ' $n$ te egalitêre interpretasie van die brief wat dalk binne die oorspronklike ontstaanskonteks vreemd sou wees. As nog 'n voorbeeld noem ek Hieronimus se stelling dat die Filemonbrief, prakties gesproke, 'n gesprek tussen Paulus en Filemon is (ten spyte van al die ander mense wat in die aanhef genoem word). Dit blyk nog steeds 'n geldige eksegetiese insig te wees. Verder is die klem wat Chrysostomus in sy homilieë oor die brief op eer-skandekategorieë plaas 'n aspek wat meer aandag in ons retoriese analises van die brief verdien. Laastens is Theodorus van Mopsuestia se stelling dat vers 17 as die hoogtepunt van Paulus se retoriese strategie gesien moet word en sy interpretasie van die begrip vennoot in terme van antieke sienings oor vriendskap bydraes wat ons retoriese analises van die brief kan verryk. Daar is nog heelwat ander aspekte wat in die loop van hierdie artikel uitgewys is, maar die belangrike punt is dat die studies van die Patristiese eksegete groter diepgang aan ons retoriese analise van die Filemonbrief kan gee. Ten spyte van'n eksegetiese misgissing hier en daar was hulle oor die algemeen noukeurige lesers van Paulus se brief - 'n navolgingswaardige ideaal!

\section{Erkenning}

Die finansiële ondersteuning van die Nasionale Navorsingstigting (NNS) van Suid-Afrika vir die navorsingsprojek waarvan hierdie studie deel uitmaak, word erken.

\section{Mededingende belange}

Die outeur verklaar hiermee dat hy geen finansiële of persoonlike verbintenis het met enige party wat hom nadelig of voordelig kon beïnloed het in die skryf van hierdie artikel nie.

\section{Literatuurverwysings}

Barclay, J.M.G., 2004, Colossians and Philemon, T\&T Clark International, London [T\&T Clark Study Guides].

Bray, G.L., 2009, Commentaries on Galatians - Philemon: Ambrosiaster, IVP Academic, Downers Grove, IL [Ancient Christian Texts]. 
Bucchi, F., 2003, 'Commentarii in Epistvlas Pavli Apostoli ad Titvm et ad Philemonem' in F. Bucchi (ed). Hieronymi Presbyteri Commentariorvm in Epistvlam Pavili Apostoli ad Philemonem Liber Vnvs, pp. 75-106, Brepols, Turnhout [Corpus Apostoli ad Philemonem Liber
Christianorum Series Latina $77 \mathrm{C}]$.

Church, F.F., 1978, 'Rhetorical structure and design in Paul's Letter to Philemon', Harvard Theological Review 71(1/2), 17-33.

De Bruyn, T., 1993, Pelagius's commentary on St Paul's Epistle to the Romans, transl. T. De Bruyn, with introduction and notes, Clarendon Press/Oxford University Press, Oxford [Oxford Early Christian Studies].

Decock, P.B., 2010, 'The reception of the Letter to Philemon in the early church: Origen, Jerome, Chrysostom and Augustine', in D.F. Tolmie \& A. Friedl (eds.), Philemon in perspective: Interpreting a Pauline letter, pp. 273-288, De Gruyter, Berlin [Beihefte zur Zeitschrift für die neutestamentliche Wissenschaft und die Kunde der älteren Kirche 169].

De Wet, C.L., 2010, 'Honour discourse in John Chrysostom's exegesis of the Letter to Philemon', in D.F. Tolmie \& A. Friedl (eds.), Philemon in perspective: Interpreting a Pauline letter, pp. 317-331, De Gruyter, Berlin [Beihefte zur Zeitschrift für die neutestamentliche Wissenschaft und die Kunde der älteren Kirche 169].

Domeris, W.R., 1993, 'Honour and shame in the New Testament', Neotestamentica 27(2), 283-297.

Elliott, S.S., 2011 "'Thanks, but no thanks": Tact, persuasion, and the negotiation of power in Paul's Letter to Philemon', New Testament Studies 57(1), 51-64.

Field, F., 1849-1862, Sancti patris nostri Joannis Chrysostomi archiepiscopo Constantinopolitani interpretatio omnium epistularum Paulinarum homilias facta, vol. 7, J.H. Parker, Oxford [Bibliotheca Patrum].

Fitzgerald, J.T., 2010, 'Theodore of Mopsuestia on Paul's Letter to Philemon', in D.F. Tolmie \& A. Friedl (eds.), Philemon in perspective: Interpreting a Pauline letter, pp. 332-363, De Gruyter, Berlin [Beihefte zur Zeitschrift für die neutestamentliche Wissenschaft und die Kunde der älteren Kirche 169].

Fitzmyer, J.A., 2000, The Letter to Philemon: A new translation with introduction and commentary, Doubleday, New York.

Friedl, A., 2010, 'St Jerome's dissertation on the Letter to Philemon', in D.F. Tolmie \& A. Friedl (eds.), Philemon in perspective: Interpreting a Pauline letter, pp. 289-315, De Gruyter, Berlin [Beihefte zur Zeitschrift für die neutestamentliche Wissenschaft und die Kunde der älteren Kirche 169].

Frilingos, C., 2000, "'For my child, Onesimus": Paul and domestic power in Philemon' Journal of Biblical Literature 119(1), 91-104.

Greer, R.A., 2011, Theodore of Mopsuestia: The commentaries on the Minor Epistles of Paul, transl. R.A. Greer with an introduction, Brill, Leiden [Society of Biblical Literature Writings from the Greco-Roman World 26].

Guinot, J.-N., 2006, 'Theodoret of Cyrus (ca. 393-458)', in C. Kannengiesser (ed.) Handbook of Patristic exegesis: The Bible in Ancient Christianity, with special contributions by various scholars, pp. 885-918, Brill, Leiden.

Hunter, D.G., 2009, '2008 NAPS presidential address: The significance of Ambrosiaster', Journal of Early Christian Studies 17(1), 1-26.

Kannengiesser, C., 2006, Handbook of Patristic exegesis: The Bible in ancien Christianity, with special contributions by various scholars, Brill, Leiden.

Kea, P.V., 1996, 'Paul's Letter to Philemon: A short analysis of its values', Perspectives in Religious Studies 23(2), 223-232.

Kelly, J.N.D., 1995, Golden mouth: The story of John Chrysostom - ascetic, preacher, bishop, Cornell University Press, Ithaca.

Krans, J., 2013, 'Who coined the name "Ambrosiaster"?', in J. Krans, B.J.L. Peerbolte, P.-B. Smit \& A. Zwiep (eds.), Paul, John, and apocalyptic eschatology: Studies in honour of Martinus C. de Boer, pp. 274-281, Brill, Boston [Supplements to Novum Testamentum 149].

Lampe, P., 1985, 'Keine "Sklavenflucht" des Onesimus', Zeitschrift für die neutestamentliche Wissenschaft und die Kunde der älteren Kirche 76(1-2), 135-137.
Lampe, P., 2010, 'Affects and emotions in the rhetoric of Paul's letter to Philemon: A rhetorical-psychological interpretation', in D.F. Tolmie \& A. Friedl (reds.), Philemon in perspective: Interpreting a Pauline Letter, pp. 61-78, De Gruyter, Berlin [Beihefte zur Zeitschrift für die neutestamentliche Wissenschaft und die Berlin [Beihefte zur Zeitschrift
Kunde der älteren Kirche 169].

Levy, I.C., 2011, The letter to the Galatians, Eerdmans, Grand Rapids, MI [Bible in Medieval Tradition]

Marriott, C. \& Pusey, E.B., 1870, Theodoreti episc. Cyri Commentarius in omnes B. Pauli epistolas II: Continens epistolas ad Ephesios, Philippenses, Colossenses, Thessalonicenses, Hebraeos, Timotheum, Titum et Philemonem, J.H. Parker, Oxford [Bibliotheca Patrum Ecclesiae Catholicae]

Mitchell, M.M., 1995, 'John Chrysostom on Philemon: A second look', Harvard Theological Review 88(1), 135-148.

Mitchell, M.M., 2001, 'Reading rhetoric with patristic exegetes: John Chrysostom on Galatians', in A.Y. Collins \& M.M. Mitchell (eds.), Antiquity and humanity: Essays on ancient religion and philosophy presented to Hans Dieter Betz on his 70t birthday, pp. 333-355, Mohr Siebeck, Tübingen.

Nottingham, E.G., 1991, The interrelationship of genre and rhetoric in the Letter to Philemon, TREN, Portland.

Quasten, J., 1960, Patrology, vol. III, Spectrum/Newman, Utrecht.

Russell, D.M., 1998, 'The strategy of a first-century appeals letter: A discourse reading of Paul's Epistle to Philemon', Journal of Translation and Textlinguistics 11, 1-25.

Scheck, T.P., 2010, St. Jerome's commentaries on Galatians, Titus, and Philemon, University of Notre Dame Press, Notre Dame.

Snyman, A.H., 2009, 'Persuasion in Paul's letter to Philemon', Acta Patristica et Byzantina 20, 178-193.

Souter, A., 1926, Pelagius's expositions of thirteen epistles of St. Paul, II: Text and apparatus criticus, Cambridge University Press, Cambridge [Texts and Studies 9.2].

Souter, A., 1927, The earliest Latin commentaries on the Epistles of St. Paul, Clarendon Press, Oxford.

Tolmie, D.F., 2009, 'Onesimus - 'n wegloopslaaf?: Oor die ontstaansituasie van die Filemonbrief', Verbum et Ecclesia 30(1), 279-301.

Tolmie, D.F., 2014, 'Die retoriese analise van die Brief aan Filemon in die lig van Johannes Chrysostomus se homilieë oor dié brief', Hervormde Teologiese Studies 70(1), 1-8.

Tolmie, D.F., 2015, 'Ambrosiaster se uitleg van die Filemonbrief en die retoriese analise van dié brief', In Luce Verbi 49(2), 1-7.

Vogels, H.J., 1968, Ambrosiastri qvi dicitvr commentarivs in epistvlas Pavlinas III: In epistvlas ad Galatas, ad Efesios, ad Filippenses, ad Colosenses, ad Thesalonicenses, ad Timothevm, ad Titvm, ad Filemonem, Hölder-Pichler-Tempsky, Wien. [Corpus scriptorum ecclesiasticorum latinorum $81 / 3$ ].

Von Harnack, A., 1918-1919, Der kirchengeschichtliche Ertrag der exegetischen Arbeiten des Origenes, J. C. Hinrichs, Leipzig [Texte und Untersuchungen zur Geschichte der altchristlichen Literatur 12.3].

Weima, J.A.D., 2010, 'Paul's persuasive prose: An epistolary analysis of the Letter to Philemon', in D.F. Tolmie \& A. Friedl (eds.), Philemon in perspective: Interpreting a Pauline letter, pp. 29-60, De Gruyter, Berlin [Beihefte zur Zeitschrift für die neutestamentliche Wissenschaft und die Kunde der älteren Kirche 169].

Wendland, E., 2010, "You will do even more than I say": On the rhetorical function of stylistic form in the letter to Philemon', in D.F. Tolmie \& A. Friedl (eds.), Philemon in perspective: Interpreting a Pauline letter, pp. 79-112, De Gruyter, Berlin [Beihefte zur Zeitschrift für die neutestamentliche Wissenschaft und die Kunde der älteren Kirche 169].

Witherington, B., 2007, The letters to Philemon, the Colossians, and the Ephesians: A socio-rhetorical commentary on the Captivity Epistles, Eerdmans, Grand Rapids, Ml. 